\title{
WHORES, MEN, AND OTHER MISFITS: UNDOING 'FEMINIZATION' IN THE ARMED FORCES IN THE DRC
}

\author{
MARIA ERIKSSON BAAZ AND MARIA STERN*
}

\begin{abstract}
The global attention focused on sexual violence in the DRC has not only contributed to an image of the Congolese army as a vestige of premodern barbarism, populated by rapists, and bearing no resemblance to the world of modern armies; it has also shaped gender and defence reform initiatives. These initiatives have become synonymous with combating sexual violence, reflecting an assumption that the gendered dynamics of the army are already known. Crucial questions such as the 'feminization' of the armed forces are consequently neglected. Based on in-depth interviews with soldiers in the Congolese armed forces, this article analyses the discursive strategies male soldiers employ in relation to the feminization of the army. In the light of the need to reform the military and military masculinities, the article discusses how globalized discourses and practices render the Congolese military a highly globalized sphere. It also highlights the particular and local ways in which military identities are produced through gender, and concludes that a simple inclusion of women in the armed forces in order to render men less violent might not have the pacifying effect intended.
\end{abstract}

Following THE GLOBAL FOCUS ON SEXUAL VIOLENCE in the DRC WARSCAPE, attention to gender in defence reform initiatives has become almost synonymous with combating sexual violence. Other explicitly gendered areas of contention, such as the question of the 'feminization'1 of the armed forces for equality reasons or for the purpose of rendering them less arbitrarily violent, have been bypassed in the frenzy to attend to the scourge of sexual violence in the global security sector reform (SSR)

\footnotetext{
*Maria Eriksson Baaz (maria.eriksson@globalstudies.gu.se) is a researcher at the Nordic Africa Institute, Uppsala and the School of Global Studies, Gothenburg University. Maria Stern (maria.stern@globalstudies.gu.se) is Associate Professor at the School of Global Studies, Gothenburg University.

1. The term feminization is often used to refer to a wide range of issues and debates, including, but not limited to the inclusion of women in the armed forces. It also refers to the question of the gendered coding of the military itself, including what types of activities it performs. It is important to note that our use of the term here does not signify an idea that the inclusion of women entails a feminization of the armed forces. Rather, we use it against the grain, to refer to a general debate and common assumptions about the gendered nature of the military.
} 
agenda. ${ }^{2}$ While an understanding of and a focus on sexual and genderbased violence (SGBV) is vital for addressing the ripples of violence caused through protracted and pervasive warring, gendered power relations are also at play in other crucial aspects of the military. Better understanding of how gender works in the military sphere is vital for the implementation of effective defence reform in war-torn societies. Similarly, better understanding of the workings of gender in specific military contexts is crucial for enabling equal access for both men and women to the military as a prime state institution - this is an official aim of the Congolese state, and one that is included in SSR efforts globally. While women and girls have formed part of the troops of both of the Congolese national armed forces as well as the various rebel groups, little attention has been directed to their experiences or their possibilities within the current processes of military integration and defence reform.

It may be argued, in short, that the main goal behind the defence reform efforts directly and explicitly addressing 'gender' is to reconfigure violent articulations of gender (masculinity) into responsible notions of militarized masculinity based on an idea of (male) soldiers as the disciplined protectors of the civil population, with a focus on women and children - soldiers who know about, understand, and respect both human rights and military regulation. According to this logic, which gains its purchase from globalized discourses about gender and SSR, ${ }^{3}$ the objective of gender-sensitive defence reform is to educate Congolese soldiers about the difference between 'good'/legal and 'bad'/illegal (masculine) behaviour in relationship to being a good soldier.

This line of reasoning seems to make good sense. However, its cogency rests on the assumption that we know what gender is and does, as well as how we can 'do gender' better. ${ }^{4}$ Yet, to date, little is known about how the Congolese national armed forces and attendant military identities are constructed through and by gender. ${ }^{5}$ Such knowledge is vital for the

2. This insight is based on our interviews with several representatives from different bodies within the EU and MONUSCO, the US army, as well as the FARDC military staff, who have explained to us what efforts regarding gender have been implemented or planned in terms of defence reform. Interviews took place during different periods in Kinshasa and Goma, 2006-10.

3. See, for example, Cheryl Hendricks and Lauren Hutton, 'Defence reform and gender (Tool 3)' (Gender and Security Sector Reform Toolkit series, Geneva Centre for the Democratic Control of Armed Forces, Organization for Security and Cooperation in Europe Office for Democratic Institutions and Human Rights, and United Nations Entity for Gender Equality and the Empowerment of Women, 2008).

4. See Maria Stern and Marysia Zalewski, 'Feminist fatigue(s): reflections on feminism and familiar fables of militarisation', Review of International Studies 35, 3 (2009), pp. 611-30. 5. But see Maria Eriksson Baaz and Maria Stern, 'Why do soldiers rape? Masculinity, violence, and sexuality in the armed forces in the Congo (DRC)', International Studies Quarterly 53, 2 (2009), pp. 495-518. 
design of contextually specific defence reform initiatives that pay attention to gendered power relations already at work. Moreover, understanding how gender works in the re-formation of identities and practices in the Congolese military may help us to better pose gender, as well as its relationship to militarized violence, as open questions. Re-thinking formulaic answers to such puzzles is vital for the formulation of responsible global security policy, and to academic theorizing about violence and gender.

It is clearly impossible to offer a comprehensive analysis of gender in the Congolese National Army (Forces Armées de la République Démocratique $d u$ Congo, FARDC). ${ }^{6}$ We therefore focus our inquiry on looking at the ways in which gender is being (re)configured through the particular lens of the 'feminization' debate, in the light of how the connections between 'gender and SSR' are currently being formulated, both implicitly and explicitly. Specifically, we focus on the ways in which male soldiers in the FARDC make sense of the presence of - and the prospect of - an increasing number of women in the army, although we also include some female soldiers' voices as points of contradistinction. ${ }^{7}$ Through this we also provide insights into the neglected issue of women's access to the Congolese armed forces, asking how gender discourses within the military work to limit/enable women's access to, and roles within, the future army.

The article draws on a research project on gender and sexuality within the Congolese Armed Forces conducted during 2006-9, and funded in full by the Swedish International Development Cooperation Agency (SIDA). It is based mainly on group interviews with 226 soldiers and offcers of various background in terms of rank, age, gender, and ethnic background. ${ }^{8}$ As we shall see, through including/excluding various and

6. In our view, the workings of gender are never static, but instead are informed by and inform a complex interplay of fluid power relations.

7. We address women's voices more fully in Maria Eriksson Baaz and Maria Stern, 'Draft Manuscript', 2011.

8. The majority of the interviews were conducted by Maria Eriksson Baaz in Lingala (which is also the general language of the army), without an interpreter. In some areas in the Kivus, where soldiers were not comfortable in Lingala, interviews were conducted with the assistance of a Swahili interpreter. We focused on soldiers and officers presently or recently deployed at the 'front' areas (approximately 80 percent of those interviewed). Approximately half the interviews were with officers and the rest with soldiers, and about 20 percent of the interviewees, soldiers and officers, were women. Roughly half of those interviewed had a background in the previous government forces, the Forces Armées Congolaises (FAC). The rest came from the multitude of armed groups integrated into the army in various phases, in particular MLC, RDC, Mai-Mai, and CNDP. For more details on methodology see Maria Eriksson Baaz and Maria Stern, 'Making sense of violence: voices of soldiers in the Congo (DRC)', Fournal of Modern African Studies 46, 1 (2008), pp. 57-86; Eriksson Baaz and Stern, 'Why do soldiers rape?'; Maria Eriksson Baaz and Maria Stern, 'The complexity of violence: a critical analysis of sexual violence in the Democratic Republic of the Congo (DRC)' (Report, Swedish International Development Cooperation Agency and Nordic Africa Institute, 2010). 
shifting masculinities and femininities in their narratives, the (male) soldiers strive to maintain the military as a particular masculine sphere where they can be military 'men' and where 'women' do not belong. Moreover, the soldiers place 'women' outside of both the zone of combat and the violence associated with combat, which they identify as distinctly masculine. This is hardly novel or unique in terms of the ways in which the 'feminization' of the military has been received in differing contexts globally. ${ }^{9}$ Many of the strategies at play in the FARDC do indeed resonate with experiences from other contexts. However, the details of the discursive strategies employed among FARDC soldiers are also embedded in the specific local context and warrant distinct analysis. For instance, one of the most common assumptions about the problems posed for the military along with female bodies - that the presence of women places the battalion at risk because of their inherent need for masculine protection - does not resonate with the FARDC soldiers' narratives. Ironically, the flip side of this assumption - that fostering the inherent 'protectiveness' of masculinity might lead to a decrease in SGBV and violence against civilians - underpins many efforts to transform hostile civil-military relations in SSR reform. ${ }^{10}$

The article proceeds as follows. First we briefly explore the notion of the 'feminization of the military'. Next, we provide a short overview of the military integration process in the DRC, including the 'state of feminization' of the Congolese armed forces, and explore some voices of women soldiers, the majority of whom advocate for women's full and equal participation in all domains of the armed forces. We then turn our attention to how male soldiers speak of the 'feminization' of the armed forces, and present the four main discursive strategies we identified in the soldiers' narratives, which can be read as attempts to 'undo' the threat of women's bodies, and maintain the masculine identity of the army and of military violence: (1) Deferral through evolutionary spatio-temporality (for example: yes, women should be allowed in the armed forces but the time is not ripe, 'here', 'yet'); (2) The zone of combat as masculine and women as weak and incapable; (3) Woman as unreliable whore; (4) Denial of (women's) femininity. Finally, we conclude with some reflections regarding how our study may be relevant in terms of SSR efforts.

\section{The feminization of the military?}

Military institutions have long been understood as the venues through which boys can achieve their natural potential as men, linking the ability

9. See Gerhard Kümmel, 'When boy meets girl: the "feminization" of the military', Current Sociology 50, 5 (2002), pp. 615-39.

10. Interview, EUSEC/EUPOL personnel, Kinshasa, DRC, 2009. 
and willingness to commit violence to certain forms of heterosexual masculinity. That the military is commonly understood as a masculine sphere is hardly a novel insight; ${ }^{11}$ indeed, while ideals of masculinity as embodying violent heroic achievement are surely reproduced elsewhere, the military has occupied a privileged role in that its specific version of masculine heroic violent achievement, committed by strong active males putting their lives at risk for the greater good of their homeland, has been openly celebrated and eroticized in the public sphere though war propaganda, memorials, movies, parades, et cetera. Given the almost galvanized connection between the military and masculinity, both in terms of the military housing predominantly male bodies and its decidedly heterosexual masculine coding, the prospect of the feminization of this sphere places more at stake than simple liberal notions of equality.

While there has been a shift in recent years in terms of women's access to the armed forces, it could be argued that this shift has not unsettled the masculine coding at the core of military institutions themselves. While the political processes of opening up spaces for women within the military is a result of political struggles for gender equality, it also reflects perceived (novel) needs of contemporary armies, the patterns of armed conflict, and military engagement worldwide. With many militaries globally engaged in peacekeeping and humanitarian interventions, increasing focus has been placed on the need for women in peacekeeping operations - especially as the UN Security Council Resolution 1325 becomes firmly entrenched in global security policy. The promotion of women's added value as peacekeepers arguably rests on assumptions about women's 'femininity' (whether socially constructed or inherent). ${ }^{12}$ Women are assumed to be ethically regulating presences who extend their 'feminine traits' to the men in their proximity, which resonates with familiar notions of women as beautiful and peaceful souls ${ }^{13}$ - notions which have

11. See for example Paul Higate and John Hopton, 'War, militarism and masculinities' in Michael S. Kimmel, Jeff Hearn, and R. W. Connell (eds), Handbook of Studies on Men and Masculinities (Sage Publications, Thousand Oaks, CA, 2005); Paul Higate, Military Masculinities (Praeger, London, 2003); Joshua S. Goldstein, War and Gender (Cambridge University Press, Cambridge, 2001); David J. H. Morgan, 'Theatre of war: combat, the military, and masculinities' in Harry Brod and Michael Kaufman (eds), Theorizing Masculinities (Sage Publications, London, 1994); Cynthia Enloe, Bananas, Beaches and Bases (University of California Press, Berkeley, CA, 2000); Sandra Whitworth, Men, Militarism, and UN Peacekeeping (Lynne Rienner Publishers, Boulder, CO, 2004).

12. See, for example, Hendricks and Hutton, 'Defence reform'. This conceptualization of femininity, as embodying victimhood and in need of special protection, is also reproduced in ways in which gender and security have emerged as important on the international agenda, through SCR 1325, 1820 and 1888. For a critique see Laura J. Shepherd, 'Power and authority in the production of United Nations Security Council Resolution 1325', International Studies Quarterly 52, 2 (2008), pp. 383-404; Natalie Florea Hudson, Gender, Human Security and the United Nations (Routledge, New York, NY, 2010).

13. Jean Bethke Elshtain, Women and War (University of Chicago Press, 1995). 
underpinned common narratives of peace and war. ${ }^{14}$ Hence, whether arguing for women's inclusion or exclusion, femininity itself (again treated as a known category) remains central; women are included - or excluded - on the basis of this 'femininity'. Women soldiers are 'not soldiers but women soldiers'. ${ }^{15}$ Moreover, by focusing the debate on the issue of peacekeeping, rather than combat and warfare, the increasing presence of women does not unsettle the masculine identity of the army. The association of combat/warfare with masculinity remains intact.

Why then might femininity pose a threat, so much so that its prospect incites heated debate, as well as violent resistance? Simply put, we understand the feminine as a 'threat' to the military in the following way. The feminine, which serves as the opposing entity in the binary pair masculine-feminine, can be seen as the 'constitutive outside' to the seemingly inherent masculinities of the military. ${ }^{16}$ Arguably however, militarized masculinity - constructed in opposition to the feminine Other - is always 'impossible' in the sense that militarization relies on ideal types of masculinity as desirable and necessary subject positions which can never be fully achieved or inhabited. ${ }^{17}$ This 'impossibility' becomes more evident with the potential or actual physical presence of women's bodies in the armed forces. The threat of emasculation posed by the presence of women's bodies is arguably manifested in attempts to maintain the (impossible) identity of militarized masculinity.

\section{Feminization of the Congolese army: a brief background}

The present Congolese national army, FARDC, was initially formed after the installation of the transitional government in 2003, and it is still being formed with the signing of new peace accords and the integration of new groups as part of what has been described as a 'never-ending process'. ${ }^{18}$ In sum, the successful integration of former adversaries into one unified armed force remains an ideal that poorly reflects the present reality. Instead the army is fractured. The units are often responsive to the former belligerents, and not to the integrated command structures.

14. See Stern and Zalewski, 'Feminist fatigue(s)' for an overview.

15. Laura Sjoberg, 'Agency, militarized femininity, and enemy others', International Feminist Fournal of Politics 9, 1 (2007), pp. 82-101.

16. See Véronique Pin-Fat and Maria Stern, 'The scripting of Private Jessica Lynch: biopolitics, gender, and the "feminization" of the US military', Alternatives 30, 1 (2005), pp. $25-54$.

17. See, for example, Stuart Hall and Paul du Gay (eds), Questions of Cultural Identity (Sage Publications, London, 1996); Paul Higate, 'Illuminating the in/visibility of the military and militarized masculinities' (Working Paper, Nordic Africa Institute, 2010); Whitworth, Men, Militarism and UN Peacekeeping.

18. Henri Boshoff, 'Demobilisation, disarmament and reintegration in the Democratic Republic of Congo', African Security Review 16, 2 (2007), pp. 59-62. 
Military integration has been strategically liberal, with little scrutiny regarding such factors as human rights abuse records, age, physical ability, or education. Most ex-combatants who want to enlist, or whose commanders press them to join, have been able to enter the armed forces. ${ }^{19}$ The only disadvantaged group in the military integration process seems to be women. The proportion of women in the ranks is very low. Their estimated numbers have dropped from approximately 5 percent within the national army before the integration of militia groups started in 2003 , to currently less than 2 percent. $^{20}$

The decrease can be attributed to failings of the disarmament, demobilization, and reintegration (DDR) and military integration processes. As in many other post-conflict contexts, only combatants carrying a gun qualify for this process. $^{21}$ Since many of the women in the armed groups do not possess a firearm of their own (often sharing with others, or performing duties other than active combat), they have been largely 'auto-demobilized' and do not reach the $\mathrm{DDR} /$ military integration centres at all, or leave them without completing the DDR process. Moreover, many commanders also do not consider women as real combatants and have not encouraged/brought them with them in the process (assuming that many women in the ranks would not enhance their status and power within the new military structure). Hence, the ways in which the processes of military integration and DDR have been designed have resulted in a steady decrease of women's participation in the armed forces.

Zaïre was a 'forerunner' when it came to 'opening up' spaces for women within the military. Already in the late sixties, soon after Mobutu had consolidated his power, young women were recruited by force as a part of a plan, inspired by Gaddafi, to create a women-only brigade. While the all-female brigade never materialized, the women recruited during this time received good training, often abroad, and initially were trained as parachutists. Most of the female officers presently holding senior officer positions come from this first generation recruited during the end of the 1960s and the beginning of the 1970s. Inspired by these women, who were often prominently displayed in military parades, other women joined voluntarily during the Mobutu period. However, the

19. For more details see Maria Eriksson Baaz, 'The price for peace? Military integration and continued conflict in the Democratic Republic of Congo (DRC)' (Africa Programme Report, Strategy Section, Swedish National Defence College, February 2011, No. 2); Eriksson Baaz and Stern, 'The complexity of violence'.

20. Estimates from interview, personnel, Ministry of Defence, Kinshasa, DRC, May 2009. 21. See, for example, Chris Coulter, Miriam Persson, and Mats Utas, 'Young female fighters in African wars: conflict and its consequences' (Policy Dialogue No. 3, Nordic Africa Institute, Uppsala, 2008); 
women who joined later during the Mobutu period neither received the same training nor enjoyed the same status as the first generation.

In general, women are largely absent from the higher ranks of the army. There are only a dozen senior officers up to colonel and no woman has yet been promoted to the rank of general. Most of the female senior officers hold administrative positions in urban areas. However, while most women are found within administration and medical care, intelligence, and logistics, most of the women we interviewed had experience from the front/combat situations (either within the national army or within the armed groups to which they previously belonged).

Arguments for full inclusion of women in all domains of the military in the Congolese army were voiced, almost exclusively, by the women soldiers interviewed. ${ }^{22}$ Indeed, this was the main difference between male and female soldiers' narratives. In most other regards (in relation to definitions of soldiering and violence, the purpose and role of the army, et cetera) women soldiers expressed views similar to those of their male colleagues. For instance, they tended to explain the use of violence against civilians - including sexual violence - in the same way as their male colleagues. $^{23}$

When it came to the question of women's inclusion and roles within the army, most women soldiers and officers argued strongly for the full inclusion of women in all domains of the armed forces, including combat and as commanders of operational combat units. Their arguments drew on women's rights to equal access, but particularly women's equal capacity for violence and combat. They attributed the present limitations posed on women within the army to discrimination imposed by the military establishment. These limitations reflected neither women's wishes nor their capacities. In fact, some of the women contended that women have more courage than men and therefore could be seen as more suitable for combat. Two female captains explained as follows:

Captain A: Many women have been fighting in the war. But if you see that still many women are within administration, it is not our fault. They (the men, the superiors) are the ones limiting us, not ourselves. They are limiting us, not us.

Captain B: In order to be in the military you have to be strong. You cannot be weak. You have to be able to cope with all sorts of things and still be strong. You cannot be afraid. You have to have courage. Many of the men are afraid, more afraid than us women. ${ }^{24}$

22. We address this more fully in Eriksson Baaz and Stern, 'Draft Manuscript'.

23. See Eriksson Baaz and Stern, 'Why do soldiers rape?'.

24. Interview, Kinshasa, DRC, June 2007. 
Hence, while there were voices arguing for a full inclusion of women, these voices were, almost exclusively, those of women themselves. As we discuss below, while some male soldiers and officers also argued for women's inclusion, these arguments tended to be restricted to 'particular' and 'exceptional' women.

\section{Strategies of resistance to the threat of feminization}

We now turn to the different strategies that the male soldiers employed when contending with the threat of the prospect of feminization: (1) Deferral through evolutionary spatio-temporality; (2) The zone of combat as masculine and women as weak and incapable; (3) Woman as unreliable whore; (4) Denial of (women's) femininity. There were no major differences in the ways in which these strategies appeared in the separate interviews. The main difference was that senior, particularly ex-FAZ/FAC officers, tended to emphasize 'evolutionary spatio-temporality', while the imagery of women as 'unreliable whores' was prominent among ordinary soldiers.

Deferral through evolutionary spatio-temporality: In contrast to women soldiers who argued for women's inclusion universally (based on women's inherent similar, or even stronger, capacity for combat) male soldiers and officers who expressed a positive attitude to the inclusion of women in commander and combat roles tended to advocate for a restricted inclusion of a few 'exceptional' women. They thus argued for relegating the feminine to a zone of exception, which, arguably, would enforce the power of the norm of masculinity, instead of undermining it. One colonel explained:

Of course women, some women, are very strong and they can do all the things that men do.... They can also be commanders. When I was in the US, there ... in the training, one of the commanders, she was a woman. She was really tough, very, very tough and all the men obeyed her.... Also we have some women commanders here [in the Congo], not many, but you know [looking at the others] this woman [her name] in [name of deployment area], she is good. Very strong. A lot of authority. ${ }^{25}$

As indicated, the exceptional women emerging in male military staff narratives were often foreigners, encountered either directly through military training abroad (restricted of course to senior officers) or mediated through (often Hollywood-produced) war movies. Only in a few cases were these 'exceptional' women Congolese. Hence, and ironically given the long presence of women in the Congolese armed forces, the explicit gendered references to Other armies tended to configure the Congolese 
woman soldier and officer (and in general Congolese women) as inferior to Western/Northern women. When discussing women's 'proper' role in the army, some soldiers and officers alluded to familiar evolutionist discourses, by referring to 'our African or Congolese women', as a special category. These 'normal' Congolese women, they explained, have not evolved as far as 'you Western women'. ${ }^{26}$ A male officer explained this in the following way:

Captain: But you know, women here are not like you women in Europe/ West [na Poto]. You have come far. You can do all sorts of things. You are courageous. Look at you. You come all the way here to speak to us. But our women here are not like that. They have not reached that stage yet [bakomi naino kuna te]. ${ }^{27}$

Most often the soldiers differentiated between 'our women' and 'you(r) women' in a seemingly culturally neutral way (to legitimize the low level of female participation in the Congolese Armed Forces). According to this line of reasoning, 'our African women' have not yet reached the same stage as you (white/European women) and hence they cannot perform all tasks within the army ... yet.

At other times these arguments echoed familiar Africanist discourses which contest perverted Western/non-African gender equality. In these accounts, Congolese women had no place in the army since women in the military would contradict the dictates of 'African' culture, thus repeating a well-worn (post-)colonial imagery of the docile and submissive African woman. Three male colonels explained this in the following way:

Colonel A: For us, sending a woman to the front. Doing that is humiliation.

Maria: For her?

Colonel B: You take away her honour, if you give her a gun, you take away her honour. She becomes a woman ... a woman, who is no longer good for cohabitation. In our culture, a woman with an armed weapon is strange. It is bizarre.

Maria: Why? Because she gives birth?

Colonel A: No, it is not that. In our culture, we see women as special, as someone with honour. If you put an armed weapon in her hands it is bizarre. You take away that.

Colonel B: But in other cultures, like in China, in Israel ... or China. ${ }^{28} \mathrm{I}$ was in China. There women do the same jobs as the men in

26. See Maria Eriksson Baaz, The Paternalism of Partnership: A postcolonial reading of identity in development aid (Zed Books, London, 2005) for an overview.

27. Interview, South Kivu, DRC, June 2009.

28. Here the Chinese army is situated in the 'developed' world, as Other. 
the army. But here it is different. We try to protect the values of our culture.

Colonel C: But we have to start somewhere. There [in other places], women have developed. But we have not come there yet [tozali naino kuna te]. In our army we would like to see other roles for women, like social care, nursing, cooking, health, logistics, and intelligence. ${ }^{29}$

Hence, the debates surrounding feminization sometimes echoed familiar colonial gendered discourses in which the Congolese were written as less evolved, but with a possibility of development and progress.

The zone of combat as masculine and women as weak and incapable: Militarized masculinity - constructed in opposition to the feminine Other - is always 'impossible'; it remains an unattainable ideal. However, as we will show here, this 'impossibility' becomes more evident with the actual physical presence of women's bodies in the armed forces. The threat of emasculation posed by the presence of women bodies is manifested in attempts to maintain the (impossible) identity of militarized masculinity.

One of the classic arguments against women's inclusion within the armed forces has been women's supposedly physical and psychological weakness, which makes them unsuitable for combat. While masculinity has been portrayed as embodying aggressiveness, physical strength, willingness to endure extreme physical danger and readiness to take lives, women have been cast as less aggressive, less daring and less able to suppress minor personal hurts, hence simply just not up to the job of combat. $^{30}$ According to this line of reasoning, including women in the armed forces will necessarily manifest itself in a weakening of the armed forces.

This representation was recurrent within the male soldiers' narratives. They described masculinity as embodying courage and a lack of fear in opposition to women, who embodied weakness and fear. Two male Colonels reasoned in the following way:

Colonel A: Women are not able to fight. Because me, I am already used to hearing the sounds of guns, I am no longer afraid. But women never stop being afraid. Even today, if somebody fires a gun here now, we men would not panic. But women will

29. Interview, Office of Chief of Staff, Kinshasa, DRC, October 2006.

30. See, for example, Stephanie Gutmann, The Kinder, Gentler Military (Scribner, New York, NY, 2000); Martin van Creveld, 'The great illusion: women in the military', Millennium 29, 2 (2000), pp. 429-42; Brian Mitchell, Women in the Military (Regnery Publishing, Washington, DC, 1998); Brian Mitchell, Weak Link (Regnery Publishing, Washington, DC, 1989). 
panic. Women also can do like if she is to run, then all of you will think that something happened and start to run. That is dangerous.

Colonel B: I have been in many wars, as a commander, but to put women at the front, honestly, no.

Maria: Why?

Colonel B: She will not make it [akosupporte te]. When the bullets... when there is gun fire, she will not take it. She will be afraid. She might even start to menstruate on the spot out of fear. ${ }^{31}$

The colonels imply a notion of ideal male soldiering which serves as the underlying condition of possibility for their narratives. They describe how women 'are' on the battlefield (panicked, afraid, cowardly, and so weak that they 'menstruate on the spot out of fear') and thus establish that all men/soldiers are not. The (masculine) qualities required were contrasted with feminized qualities. Being 'afraid' (like a 'woman') was considered to be a sign of weakness, as unfitting for a soldier. ${ }^{32}$ As in other military contexts, ${ }^{33}$ many soldiers also reiterated that being called a 'woman' was a common insult to a soldier during training: 'you are weak like a woman' [olemba lokola mwasi].

Combat was often inscribed as masculine in opposition to acting as guard, which was coded as feminine. In line with this coding, many soldiers proposed that women were more suited to the police force, hence feminizing and configuring the police force as accommodating an inferior masculinity. ${ }^{34}$ In a telling analogy with the story of the creation of 'man' and 'woman' in the Bible, one soldier expressed himself in the following way:

Sergeant: For me, I see ... just like God created women from the man's rib, I see that the Police Force is created from the rib of us in the Armed Forces, the FARDC. They took our rib and made the Police force. A police is someone who is in the towns, who is guarding [kokengela] that is a job for women.... I think they should take all the women in the Army and put them in the Police. We are the guerrillas; we are fighting in the war. ${ }^{35}$

In line with this differentiation between acting as guard and fighting wars, few soldiers and officers argued for a full exclusion of women. In fact,

31. Interview, Ministry of Defence, Kinshasa, DRC, October 2006.

32. Eriksson Baaz and Stern, 'Making sense of violence'.

33. See Cynthia Enloe, Maneuvers (University of California Press, Berkeley, CA, 2000).

34. R. W. Connell, Masculinities (Polity, Los Angeles, CA, 1995); Higate, Military Masculinities.

35. Interview, Kinshasa, DRC, July 2006. A further discussion of the relations between the army and the police in the context of current SSR efforts, while highly important, is beyond the scope of this article. 
most interviewed were not critical of women's presence in the army - as long as they remained within predefined zones, particularly within medical and social services, administration, intelligence, military courts, and various other support roles. Some even argued that it is good with 'a woman's touch' in the army: ${ }^{36}$

Male Captain: Women are needed in the army. The army is not just combat. It is all these other areas - medicine, social issues [affairs sociale], intelligence. The army is just not combat. It is a lot of areas. And women can be better [than men] in those other areas. So we need them [bakoki kozanga te]. ${ }^{37}$

Hence, women and femininity could be included - yet not fully and, arguably, not in the core activities of the military: fighting with violence. As long as they remained 'outside' of combat, then women's femininity might even be of benefit, although as a light 'touch', to the masculine military mission.

As demonstrated above, the army was, in a familiar way, discursively divided into different gendered spheres: the masculine sphere of combat, understood as the real army, and the rest - the sphere of feminine support. The domain of combat was populated by 'the real soldiers'. As DeGroot concludes, it is 'the potential to kill which determines real soldierly identity and is the qualification for the status and social capital which accrue from that identity'. ${ }^{38}$

This preoccupation with combat and the efforts to demarcate combat from non-combat roles can be read as an attempt to maintain the masculine identity of the armed forces. Through this definitional gatekeeping, women can be included without an imminent threat of emasculation of the armed forces. As long as women are kept outside the zone of combat (or alternatively are masculinized and configured as men, see below) they constitute no real threat to militarized masculinity (because they are not real soldiers anyway). The 'real' army still remains intact, inhabited by the 'real' soldiers who fight. According to one male corporal:

Have you seen any wounded women soldiers? No, because there are none. They do not fight, they do not die. They are not real soldiers. If they want equality, they should get it. Then they should fight in the war like we do. ${ }^{39}$

36. Adjutant, Kinshasa, September 2006.

37. Interview, North Kivu, DRC, October 2009.

38. Gerard J. DeGroot, 'Introduction to Part 1: Arms and the woman' in Gerard J. DeGroot and Corinna Peniston-Bird (eds), A Soldier and a Woman (Pearson Education Limited, Harlow, 2000), pp. 3-17.

39. Kinshasa, July 2006. 
The citation above is (needless to say) a narrative that stands up poorly to the experiences of the women soldiers. As emphasized above, women are present and also perform combat roles in the Congolese armed forces, and some have been wounded and killed.

However, the common portrayal of women as special objects of protection was largely absent in the DRC context. Military traditionalist arguments against women's inclusion in many contexts (not least in the US) draw heavily on a gendered distinction between protector (men) and protected (women). In this familiar gender coding, women are inherently in need of protection. In addition to being presented as a violation of natural and desired gender relations, the inclusion of women is also presented as a serious threat to combat efficiency, since military resources and energy supposedly will be used to protect the women within the army, rather than engaging with the enemy. ${ }^{40}$

In the DRC context, women were described as 'weak'; but they did not elicit, require, or deserve special protection from men. Indeed, one of the main differences in the ways in which the feminization debate was articulated in the DRC was the relative absence of arguments connected to the differentiation between man/the protector and women/the protected; simply put, women were not cast as 'objects of protection'. This idea was not even embraced when brought up explicitly in the interviews, as demonstrated in the following exchange:

Maria: One argument in other places is that the inclusion of women makes the army feeble because women are in a special need of protection and if there are women within the army, men would be concentrated on their safety, for example to free them if they are taken as POWs ... and that makes the army less effective.

Corporal 1: But the soldier's role is not to protect women. The role is to protect the nation [ekolo]. There are both men and women in the nation. When you join the army you are to protect the whole nation.

Corporal 2: Also, when it comes to hostage, it is the same with men. You try to save also another male soldier. There is nothing special with women.

Corporal 3: But at the same time there is a double risk with a woman soldier if she is taken hostage, because of rape. That happens a lot. That is why when you are in combat you try not to expose the women so much. Because if they catch a woman

40. See Gutmann, The Kinder, Gentler Military; van Creveld, 'The great illusion'; Mitchell, Women in the Military; Mitchell, Weak Link. 
she can be weak. A woman can be weak. She can marry the enemy [laughing] when they catch her. If she is working in intelligence/as spies - that is a problem. ${ }^{41}$

While the deployment of women was presented as a potential risk indeed, the risk was not mainly described as a risk emanating from men's supposed natural calling to save and protect women, but from the weakness and unreliability of women themselves.

Moreover, it must be pointed out that the notion of 'heroic masculine violent achievement' central to many other militarized narratives ${ }^{42}$ was largely absent in soldiers' narratives and was expressed almost exclusively in the context of the feminization debate. Otherwise, the interview texts were characterized by a general absence of a celebration of, or aspiration to, heroic violent achievement. There were few references to iconic idolized soldiers or officers who sacrificed themselves and/or notched up heroic achievements at the front lines. Furthermore, soldiers overwhelmingly spoke of administration - working behind a desk - as the ultimately desirable position. ${ }^{43}$ For them, the ideal soldier was intimately tied to the ideal notion of masculine 'provider'.

Woman as unreliable whore: One of the areas in which a 'women's touch' was needed was discursively linked to a sexualized image of the woman temptress. ${ }^{44}$ While similar in relegating the feminine into specific and circumscribed zones, this discursive tactic reflects a familiar Madonna/whore dichotomy, and emphasizes the 'whorish' sides of femininity. One of the tasks presented as particularly suited to women was within military intelligence, as 'spies at the front'.

Male Adjutant: Women are needed. Especially in intelligence. Women have special talents [laughing]. They are much better in getting information from the enemy. There, we cannot beat them. Men are weak when it comes to women. A nice woman, if she flatters you, satisfies you, you become weak [feeble] and you talk. ${ }^{45}$

This role was also portrayed as particularly suitable for women by some women soldiers themselves. While women tended to be critical of the idea that there are special jobs for men and women in the army, some brought up intelligence work in the same vein as the Adjutant cited above. In doing so they also repeat and reproduce the sexualized image of

41. Interview, Kinshasa, DRC, September 2006.

42. See Higate, 'Illuminating the in/visibility'.

43. See Eriksson Baaz and Stern, 'Making sense of violence'.

44. See Laura Sjoberg and Caron E. Gentry, Mothers, Monsters, Whores (Zed Books, London, 2007).

45. Interview, North Kivu, DRC, October 2009. 
women constructed in the armed forces - an image which works to exclude them from combat.

One common argument among military traditionalists is that feminization erodes unit cohesion through fraternization and sexual distraction. According to Mitchell, 'the presence of women inhibits male bonding, corrupts alliance to the hierarchy, and diminishes the desire of men to compete for anything but the attentions of women'. ${ }^{46}$ This argument draws upon a familiar narrative which sexualizes women engaged in violence: the 'whore narrative', which has haunted women in the armed forces globally. As Sjoberg and Gentry conclude: 'women who fight or are close to it historically have been assumed to be sexually depraved, and have frequently been described not only in the language of harlotry, but actually as whores'. ${ }^{47}$ This narrative is particularly strong in the DRC context.

The soldiers and officers interviewed often described the presence of women as a source of distraction from the main work of soldiering. Importantly, they emphasized that women's presence was a potential source of conflict among the men and destroyed the chain of command.

Male Sergeant: It is not good with women in the army. They destroy the chain of command. She will come here and then she maybe finds an officer, and becomes his woman [mwasi na $y e /$ his mistress]. Then, if you have her under your command, you will not be able to command her. She will say "You cannot tell me to do that, I am the woman of Major X". You might even get in trouble, because she can go to him and say that you treat her bad and then he can also punish you. ${ }^{48}$

Hence, in line with other military traditionalist arguments and the 'whore' narrative, women were described as destroying the army from within by distraction and fraternization. They thus inhibited male bonding and destroyed chains of command. The blame here is placed on women through the time-worn imagery of the fallen woman leading the man - and humanity - into damnation and ruin. As the same time, this configuration reflects a highly ambivalent and contradictory conceptualization of masculinity, as embodying at the same time strength, dependability, and stoicism, as well as vulnerability to the cunning seductive nature of the feminine Other. One captain underscored how, according to him, all women in the armed forces were there to sell their bodies for money:

46. Mitchell, Women in the Military.

47. Sjoberg and Gentry, Mothers, Monsters, Whores, p. 44.

48. Interview, Kinshasa, DRC, September 2006. 
They are prostitutes/free women $[n d u m b a]$. They have joined because they did not get a husband. Or maybe the husband died. They come here to look for men. But they are dirty [salite]. They are sluts [kindumba trop $]{ }^{49}$

Another familiar imagery of femininity as embodying unreliability and betrayal also emerged in the interview texts. The implied 'truth' of male dependability underpinned the claim of women's duplicity, and was constructed in opposition both to the civilian, but particularly, the feminine Other. The narratives often featured Biblical symbols such as Eve and Delilah, symbolizing the unreliable vindictive temptresses who could signify the ruin of a man, and a whole battalion at war. A group of soldiers explained this in the following way:

Soldier A: For me, the way I see it, women have no place in the army. They should be taken out of the army because they don't fight, so [a woman] has no role in the Army. Soldiers cook their own food. She has no work in the army.

Maria: Why? Can she not fight?

Soldier A: No endurance. Also, you cannot trust her ... she can decide to leave and betray us.

Maria: $\quad$ A man would not do that?

Soldier A: Well that is quite difficult/rare [mua pasi]. The men who betray us are the leaders [referring to an earlier discussion of how the military leaders embezzle salaries, food or equipment].

Maria: But why is it just women [who betray]?

Soldier B: Because when it comes to betrayal, women are first. They are feeble, when they see money or when she sees the enemy.

Soldier C: Or she will be afraid that they will kill her and she will just spill it all out [the secrets]. ${ }^{50}$

In the soldiers' narratives, femininity embodied weakness, the inability to cope with and resist pressures from the enemy. The insistence that woman are unreliable, as evidenced in this quotation, however, could not quite conceal a seeming 'gap' in the coherence of this narrative. Indeed, the very need for such insistence and repetition of this story-line could be understood as an attempt to mask the male soldiers' own unreliability as well as the unreliability of their (male) superiors - referred to in the above quotation - in a dysfunctional military system with parallel chains of commands, wide-spread involvement in unofficial economic activities, and other erosive practices. ${ }^{51}$

49. Interview, South Kivu, DRC, June 2009.

50. Interview, Kinshasa, DRC, August 2006.

51. Eriksson Baaz and Stern, 'The complexity of violence'. 
The supposed undependability of women was also the main reason why some were critical of the use of women within military intelligence. While a majority of the male (and some female) soldiers and officers stated that intelligence work was especially suited for women, some maintained that the use of women in intelligence work is also a very risky enterprise, since women are 'weak and unreliable and can decide to go over to the enemy side'. Some argued instead that men can do intelligence work just as well, by disguising themselves, for example as 'mad/ mentally retarded', and hence, as a supposedly harmless (feminized) person. In a similar way, some questioned that women should cook in the army since a woman could decide to 'turn on you and poison the food'.

Importantly, the image of femininity as embodying unreliability and betrayal appeared in relation to women in general and not only women in the army. The (male) soldiers told us that if a woman sees that other better opportunities present themselves, a woman will 'leave you or cheat on you'. While the 'whore narrative' was particularly strong in relation to women soldiers, in their capacity as colleagues and/or potential wives/girlfriends, it also appeared strongly in relation to civilian wives and girlfriends. The particular strength with which the 'whore' narrative emerged in the DRC military context can partly be seen as a reflection of dire living conditions and feelings of emasculation connected to failures to live up to the provider role. In this way, general feelings of emasculation connected to one's 'private' role as father and husband also spill over into the military sphere, feeding into representations of women within the army. ${ }^{52}$

However, in a manner similar to the division of the army into different spheres, some more exclusively masculine than others, the 'whore' narrative could also be interpreted as a way to maintain the heterosexual masculine identity of the armed forces. Through this narrative, women soldiers become demilitarized through sexualization. ${ }^{53}$

Denying femininity: Another reflection of attempts to undo or reverse feminization in the interview texts was to deny the femininity of the women soldiers, to masculinize them. The logic appears as follows: if women soldiers are no longer women they no longer constitute a threat. The following words speak clearly of the masculinization 'necessary' in order for women to be defined as a 'real' soldier:

Male Corporal: But some women soldiers, some also do a good job, there are some. And if you look at them you will see that no this person is a man. She has become like a man. She

52. Eriksson Baaz and Stern, 'Why do soldiers rape?'.

53. Sjoberg and Gentry, Mothers, Monsters, Whores. See also Rachel Woodward and Trish Winter, Sexing the Soldier (Routledge, New York, NY, 2007). 
has got the mentality of a man. She has taken the mentality of the army and put it in her heart. ${ }^{54}$

Male Corporal: Some women, some women you see in the army are like men. They are tough, brutal, more brutal than us men. They are without pity [bazangi mawa]. They are no longer women. They have become like men, worse than men actually [laughing]. ${ }^{55}$

These military staff equate the 'mentality of the army' with the 'mentality of a man', thus eradicating any discrepancies between the two categories. This 'male' mentality cannot reside inside a 'real' woman; if she does a 'good job' as a soldier, she will have been transformed into a man. The 'masculinity' of the male soldiers as strong, courageous, rational protectors/warriors remains (discursively) the coherent domain of men, and the femininity against which it is defined is kept at bay as separate.

The strategy of 'denying femininity' may also have yet another underlying rationality, which came to the fore when we asked if the presence of women might reduce the amount of sexual violence committed by the soldiers. As noted above, this is a common assumption behind many SSR efforts to include women. While we had intended the question to address many of the logics presented earlier about the 'beneficial' or 'curative' effects of women on the behaviour of men, we were instead met with the following response, which drastically misunderstood our intention, but revealed unexpected reasoning:

Male Lieutenant: No, I do not think that women in the army will reduce rape [of civilians] by satisfying our needs. Also many, if you look at them, you don't look at them like that. We no longer see them as women. They have become like men, they are hard [pointing at the features] and the skin is rough, no... you don't want be with them [sexually]. ${ }^{56}$

Hence, soldiering women cannot 'exist' in the zone of combat, or 'inside' a particular form of military violence, because their femininity in conjunction with the heterosexual 'masculine' military mentality presents an impossibility. Indeed, according to the above quotation, the 'proof' that these women have 'become like men' resides in the lack of heterosexual desire their bodies arouse in the 'real' soldiers' when they gaze upon them. In this sense, the male gaze is endowed with the power to strip women of their femininity, which in turn, is measured by their sexual

54. Interview, Kinshasa, DRC, September 2006.

55. Interview, North Kivu, DRC, October 2009.

56. Interview, Kinshasa, DRC, September 2006. 
desirability. That these women 'fail' to arouse because they are undesirable confirms that the male soldiers regarding them are indeed 'real' heterosexual male soldiers. The threat that their undesirability might indicate sexual disinterest as a result of the male soldier's homosexuality/femininity/weakness is thus (discursively) waylaid.

While these rationalities are hardly explicit, they nonetheless warrant careful reflection if the aim of including women in the army is to 'cure' violent masculinity by example and the generalized spread of moral feminine purity. According to the male soldiers' narratives, female soldiers (discursively) 'become (violent) men' through their exposure to and involvement in violence. If their transformation into 'men' does not occur and they remain 'women', then, these narratives tell us, their purpose is, coarsely put, to provide sexual satisfaction to the male soldiers so that they do not 'need' to take sex by force; to rape. ${ }^{57}$ In sum, in the soldiers' narratives for male soldiers to be masculine men, the female soldiers must become also masculinized, albeit occupying the role of 'subordinate masculinity'. ${ }^{58}$ This strategy, however, invariably fails, and, we would argue, the quest for fulfilled masculinity continues - often with violent results.

\section{Concluding remarks}

In the above paragraphs we have explored the different and interrelated strategies through which male soldiers attempt to contend with the threat posed by the presence and the prospect of the 'feminization' of the national armed forces in the DRC. By paying attention to these different and even contradictory strategies, we are able to glimpse the ways in which military identities are already constructed through and by gender.

Importantly, in the soldiers' narratives, the 'inclusion' of women 'inside' a particular form of violence associated with combat and 'inside' the military is presented as an ontological threat to the military and the (masculine, heterosexual) soldiers. In short, if the military body is no longer masculine and military violence no longer the domain of 'men', then the fragile promise of being a good, strong, military man, which pledges stature, respect, and fulfilment, and perhaps above all, an identity in which to invest, is thwarted. ${ }^{59}$ This threat, therefore, must be annulled, or at least mitigated. The soldiers we spoke to employed various discursive strategies through which they attempted to mitigate, defer, or negate the presence of women in the military and the attendant associations of

57. See Maria Eriksson Baaz and Maria Stern, 'Why do soldiers rape?'

58. Connell, Masculinities; R. W. Connell, The Men and the Boys (University of California Press, Los Angeles, CA, 2001).

59. See for example, Hall and du Gay (eds), Questions of Cultural Identity; Whitworth, Men, Militarism; Higate, 'Illuminating the in/visibility'. 
women inside 'male' combat-related violence. In so doing, they attempted to repair and resettle the taken-for-granted masculine identity of the armed forces, unsettled by the factual or potential inclusion of women, and the general dysfunction of the army.

As was evident in the many ways in which familiar discourses resonated in the soldiers' texts, globalized discourses and practices render the Congolese military a highly global(ized) sphere, with similarities with other militaries globally in terms of norms, codes, structures, and practices. ${ }^{60}$ Despite these obvious similarities, the Congolese army has been portrayed largely as a vestige of pre-modern barbarism, unconnected and bearing no resemblance to the world of modern or - as often argued post-modern armies. ${ }^{61}$ This portrayal is clearly erroneous. Despite their terrible track record in terms of human rights abuses, soldiers in the DRC armed forces present images of themselves that adhere to universalized military codes, which celebrate discipline and allegiance to chains of command. ${ }^{62}$ They laud their role as protectors of the population and human rights. ${ }^{63}$

Like most other armed forces, the Congolese army has always existed in a global landscape, shaped not only by colonial history, but also by various relations of post-independence military cooperation. The multitude of arrangements initiated during the Mobutu period - involving cooperation with diverse countries such as China, the US, Israel, France, and Belgium - and the present post-conflict security reform processes involving various military actors such as the UN, EU, Angola, China, Belgium, the US, et cetera - have surely shaped (not only/mainly in fortunate ways) the institutional set-up of the army, including the gender identities produced through militarization. As we saw in many of the quotations above, soldiers and officers in the Congolese national armed forces firmly located and negotiated their military gendered identities and arguments against/for 'feminization' by relating to other imagined gender relations globally.

Nonetheless, our reading of the FARDC soldiers' narratives highlights that the ways in which military identities are produced through masculinity/femininity (as well as vice versa) are also locally specific. The local

60. See Enloe, Maneuvers.

61. For a discussion of the post-modern army see Charles C. Moskos, John Allen Williams, and David R. Segal (eds), The Postmodern Military (Oxford University Press, Oxford, 2000).

62. See also Eriksson Baaz and Stern, 'Making sense of violence'.

63. Sexual violence cannot be explained as a result of soldiers being unaware of these 'global' military codes or their immersion in a pre-modern moral vacuum; rather, it is located in failed military integration processes and other forms of institutional dysfunction. See Eriksson Baaz and Stern, 'The complexity of violence'; Eriksson Baaz and Stern, 'Making sense of violence'. 
renditions of familiar discourses did not simply repeat arguments and gender identities articulated elsewhere. For example, the soldiers we interviewed did not celebrate violent heroic masculinity, in a familiar Rambo-like manner. ${ }^{64}$ Nonetheless, they strove to maintain the zone of combat as a particularly masculine realm and 'women' as a threat to the efficacy of combat (through, among other story-lines, their inherent weakness). However, they did not do so by evoking the seemingly perennial gendered protector/protected binary. Moreover, while being a classic narrative, the 'whore' narrative was particularly strong and embedded in the DRC military context. The strength with which the 'whore' narrative emerged can partly be seen as a reflection of dire living conditions and feelings of emasculation connected to failures to live up to the prevailing ideals of masculinity, including a role as provider, which is closely linked to the ways in which gender relations are being reconfigured in the DRC warscape. Furthermore, in their attempts to deny the femininity of women soldiers, quite surprising interpretations of the notion that women 'civilize' men's barbaric propensities for (sexual) violence through their curative moral presence emerged.

Careful scrutiny of local particularities, as well as comparative studies, are therefore needed if we are to gain a better of sense of how militaries are (re)produced and act local-globally. In the light of our concern with (in part) internationally engineered defence reform in the DRC and its effects, understanding the FARDC within a global context becomes crucial. To illuminate this point, it is helpful to return to the absence of the 'protector/protected' dichotomy in the soldiers' narratives. Many observers would conceptualize the lack of FARDC (male) soldiers' sense of themselves as (inherent) protectors of women (who, in turn, warrant such protection) as a failure that causes violence against women in the $\mathrm{DRC}$, in particular rape. According to this line of reasoning, violence against women must be understood as a consequence of the failure of Congolese men to act in a way that is expected by 'real' honourable men and soldiers (that is, to protect women). Educational efforts are therefore designed to 'correct' this ignorance.

Such an interpretation and the consequent education efforts, however, are deeply problematic as well as (arguably) ineffective. Violence against women is a global phenomenon recurrent also in societies celebrating the $\mathrm{man} /$ protector, women/protected. Moreover, while it is violence against women - in particular sexual violence - which has attracted the lion's

64. Indeed the successful, aspirational, masculinity, as reiterated in the soldiers' narratives, was symbolized by a wealthy, urban man who works in an office, owns a luxurious house and a nice car, and is surrounded by many women (not the 'man-fighter' in the wild). See Eriksson Baaz and Stern, 'Making sense of violence'. 
share of attention among outside observers of the DRC, other violence, also against civilian men, is committed on a massive scale. Sexual and gender-based violence, like all violence committed by security sector staff, must be understood in relation to a myriad of factors such as learned behaviours, (failed) military integration processes, hostile civil-military relations, experiences of imagined (and real) marginalization and (imagined) needs of reasserting power and authority and other ideals related to militarized masculinity - not simply to a 'failure' to recognize an inherent victimhood of women. ${ }^{65}$ Ultimately, our reading of the complex ways the soldiers discursively waylaid the 'feminization' of the armed forces suggests that a simple 'inclusion' of women in the armed forces in order to render men less violent might not have the 'pacifying' effect intended.

Understanding the relationship between gender and military reform is particularly important at this juncture in Congolese history, which is characterized by efforts to rebuild the armed forces after over ten years of (still ongoing) conflict. Such knowledge is vital for the design of contextually specific defence reform initiatives that pay attention to how gendered power relations are already at work, and that redirect the implementation of programmes based on generalized assumptions about gender and what gendered 'inclusion' into the military may imply, towards programmes better suited to the gendered complexities of the current FARDC.

65. Eriksson Baaz and Stern, 'The complexity of violence'. 